\title{
UPPER HOLOCENE PALEOCEANOGRAPHY OF INNER MIRAMICHI BAY
}

\author{
F.J.E. WAGNER and C.T. SCHAFER \\ Geological Survey of Canada, Bedford Institute of Oceanography, Dartmouth \\ Nova Scotia, CANADA B2Y 4A2
}

\begin{abstract}
Changes in sediment texture and in foraminiferal and molluscam assemblages observed in three vibracores collected in Miranichi Inner Bay reflect the development of a barrier island system across the mouth of the Bay, and the opening and closing of channels between the islands. The barrier is.land system apparently developed initially between 4400 and 3600 Cl4 years B.P. Opening and infilling of Huckleberry Gulley during the past 2300 years is indicated by changes in the proportions of estuarine and open bay asserablages of benthonic forminifera. Mollusc and foraminifera data do not always suggest the some paleoenvironmental conditions at any given place and time, but they are in good agreement with respect to the direction of paleoenvironmental trends.
\end{abstract}

\section{INTRODUCTION}

This study presents an interpretation of temporal variations in sedimentary deposition and in certain elements of the benthos in Miramichi Inner Bay during the past approximately 4500 years. It is based on evidence from three 10-cm vibracores obtained during the winter of 1977 (FIg. 1). Core 12B was collected from the western part of the Inner Bay north of Pointe aux Carr, Core 134B was raised northwest of Bay du Vin Island, and Core 100A came from Bay du vin off the southwestern shore of Bay du vin Island. The cores were sampled at $20-\mathrm{cm}$ intervals for foraminifera and molluscs. Additional material was taken from those intervals of the the split cores in which molluscs were observed. In addition to the study of the fossil assemblages, sedimentary structures were evaluated and radtocarbon dates were determined at two levels in each core (Fig. 2). The cores were sampled also at $20-\mathrm{cm}$ intervals for foraminifera and molluscs. Additional mollusc material was taken where observed in the split cores.

\section{SEDIMENTARY STRUCTURES}

$X$-radiographs showed that Core $134 \mathrm{~B}$ was structureless throughout much of its length, and small shell layers occurred with greater frequency in the 90- to $290-\mathrm{cm}$ interval. Bedded sediments were best developed between the top and the $85-\mathrm{cm}$ level of Core $12 \mathrm{~B}$. In Core 100A bedding was distinctive in the 20 - to $100-\mathrm{cm}, 160-$ to $170-\mathrm{cm}$ and $225-$ to $255-\mathrm{cm}$ intervals. No consistent relationship was observed between bedding features and faunal content.

\section{CHRONOSTRATIGRAPHY}

Radiocarbon dating of total organic matter in the sediments at two levels in each core * (Kruger Enterprises Nos. GX-4947, 4948, 4949, 5401, 5402, 5403) yielded a range of values between 1300 and 4500 years BP approximately. Correlation of species profiles in Cores 134A and 134B indicated that between 32 and $37 \mathrm{~cm}$ of sediment were missing from the top of Core 134B. This apparent removal of sediment was confirmed (J.N. Smith, pers. comm.) by the anomalously low $\mathrm{Pb}^{210}$ activities measured throughout the upper $10-\mathrm{cm}$ intervals of the core.

The pollen stratigraphy of the cores (McAndrews 1977) is consistent generally with the $C^{14}$ dating results. Only the late Holocene $C_{3}$ pollen zone is represented, which indicates that the sediments were. deposited during the past 5000 years. Unfortunately, MARITIME SEDIMENTS, Vol. 16, Nos. 1, 2, and 3, pp. 5n Ia.

*Kruger Enterprises Inc. Geochron Laboratories Divts.ton, 24 Blackstone Street, Cambridge, Massachusetts 02139 the $C_{3 b}-C_{3 c}$ pollen subzone boundary, which reflects the influence of European settlement and land cultivation on the occurrence and proportion of certain pollen species, is poorly defined in the upper $20 \mathrm{~cm}$ of the cores and is unreliable for stratigraphic correlations.

\section{UPPER HOLOCENE PALEOCEANOGRAPHY}

Foraminifera

Modern foraminiferal distributions were described by scott et a.l (1977). In the older cored sediments the large proportion of Elphidium excavation clavaturn (Cushman) from the portion of Core 134B dated about 3400 to 2400 years BP $(100 \mathrm{~cm}$ to $300 \mathrm{~cm}$ approximately) indicates a comparatively open-bay environment (Fig. 2). Pxior to 3300 years BP a phase of constricted circulation, i.e. a transitional environment, is indicated in core $12 \mathrm{~B}$ by the increased numbers of Ammotivm cassis (Parker) and (or) the presence of Miliammina fusca (Brady). Thts transitional environment alternates with an open-bay environment between about 4400 and 2800 years BP.

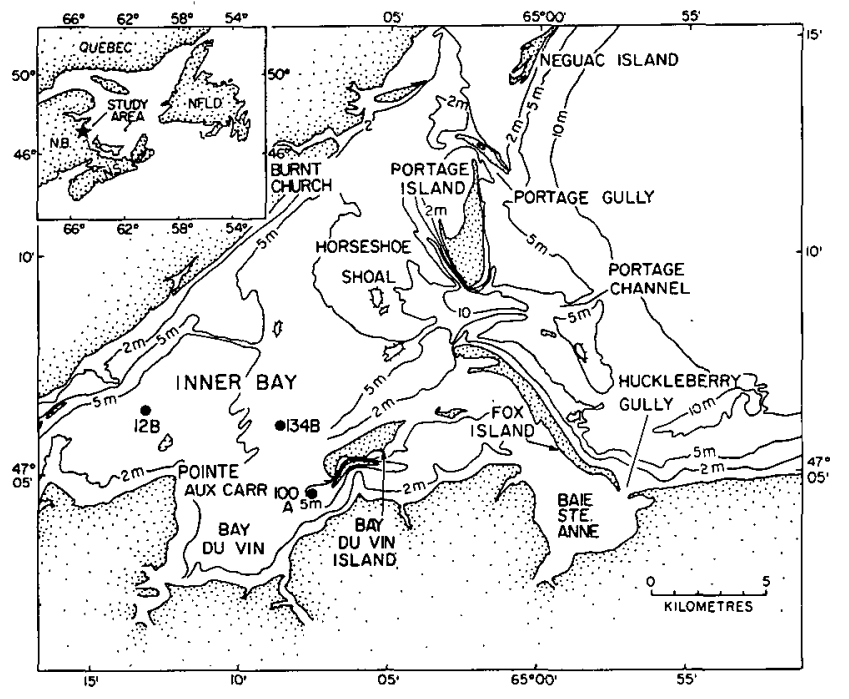

FIG. 1 Location of vibracores, Miramichi Inner Bay 


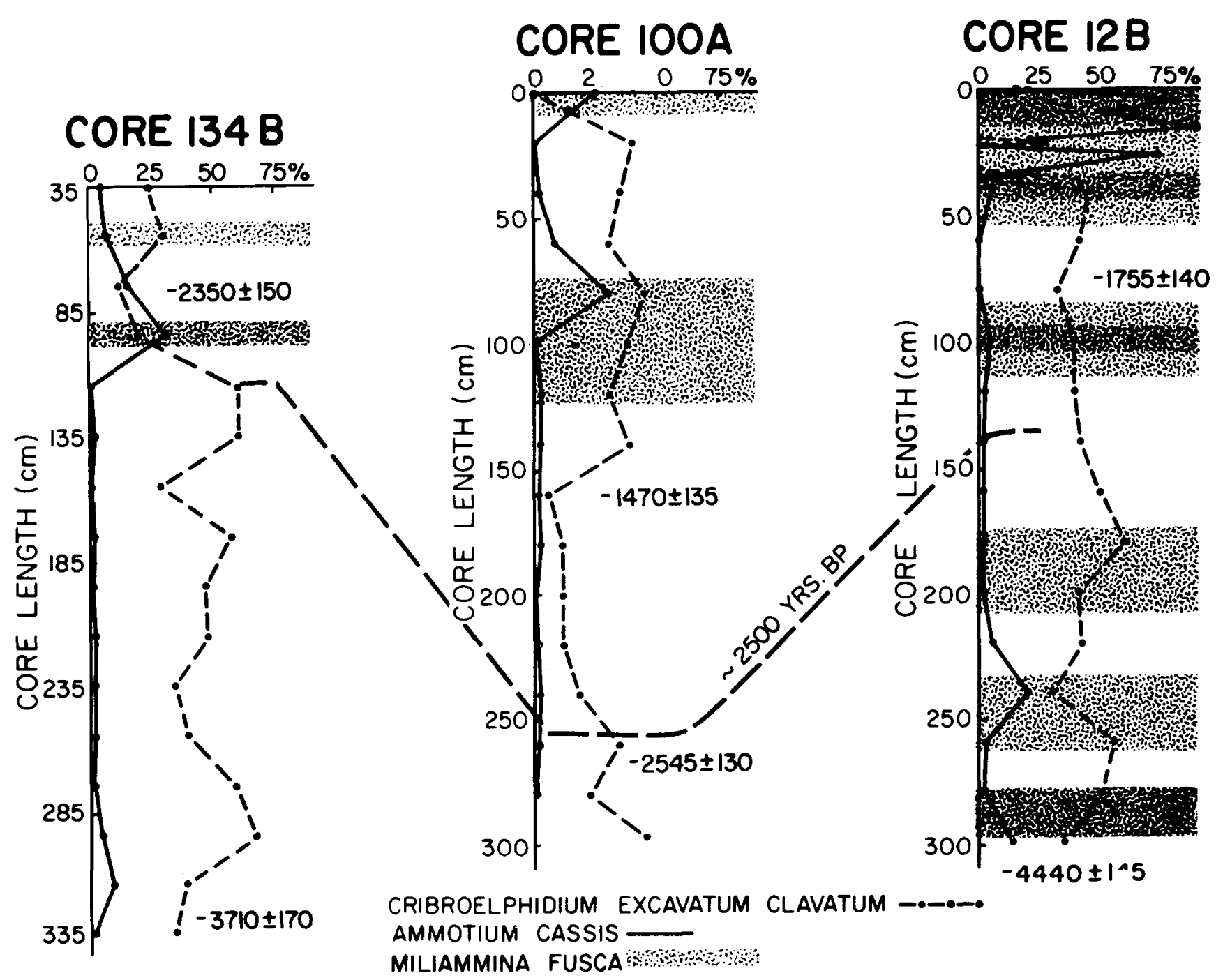

FIG. 2 Comparison of the occurrence of foraminiferal index species between cores. Note: Cribroelphidlum excavatum clavatum = Elphidium excavatum clavatum.

During the past 2500 years the western part of the Inner Bay gradually developed its distinctive transitional or lower estuarine character. This transitional environment has become relatively pronounced at station $12 \mathrm{~B}$ during the past 1000 years, probably because of the proximity of the Miramichi River. However, high percentage of $E$. excavatum clavatum at station $100 \mathrm{~A}$ is suggestive of a change in circulation that promoted the development of a relatively open-bay benthic environment from about 1300 to perhaps 200 years BP in eastern Bay du Vin, and in the waters adjacent to the southern coast of Bay du Vin Island. The most recent foraminiferal record shows high $A$. cassis and $M$. fusca percentages that suggest the accelerated redevelopment of a distinctive transitional environment adjacent to the south coast of the Island, and the alternation of open-bay and transitional conditions in the part of the Inner Bay lying to the north of Bay du $V$ in (i.e., near station $134 \mathrm{~B}$, Schafer et al, in preparation).

\section{Mollusc}

An evaluation of the grouping of the living molluscs based on grab sample collections indicates the occurrence of three assemblage zones in the Inner Bay (Fig. 3). These include an upper estuarine. assemblage zone marked by the dominance of the pelecypod species Mulinia lateralis (Say), a transitional zone characterized by the gastropods Nassarius trivittatus (Say) and Acteocina canaliculata (Say) with $M$. Zateralis subordinates, and a more saline open-bay zone with $N$. trivittatus and $A$. canaliculata dominant and $M$. lateralis lacking. Molluscan assemblages in the cores are referable to these three modern assemblage zones. These assemblage zones have been compared schematically between cores on a time-equivalent basis (Fig. 4). Core $12 \mathrm{~B}$ provides the only fossil record for the conditions that prevailed as early as 4500 years BP. At that time there was apparently freer access of marine water well into the Inner Bay. The 




FIG. 3 Areal distribution of modern molluse assemblage zones.

species of molluscs from the bottom of the core suggest open-bay conditions. Salinities were, therefore, presumably no lower than about $27 \%$ throughout much of the Bay at that time. By about 4200 years BP, upper estuarine conditions had developed in the western part of the Bay (near station $12 \mathrm{~B}$ ). The reduction in salinity may have resulted from a reduction in the ingress of marine waters, an increase in river input, or a combination of the two. Barrier islands forming across the mouth of the estuary could have affected the inflow of marine waters. The molluscs point to an oscillation between transitional and upper estuarine conditions between about 2700 and 2300 years BP, followed by a long interval during which transitional conditions may have prevailed in this part of the bay. The only definite record for the transitional zone dates at about 1000 years BP. The molluscan record from core 134B begins about 3700 years ago and suggests upper estuarine salinities in this part of the bay at that time. The situation was apparently unchanged until about 2900 years BP, except for a brief interval around 3400 years BP when the assemblages suggest the existence of transitional conditions. From 2900 to 2500 years BP transitional conditions were again present at this site and also at the site of core 12B. The subsequent change to less saline bottom water conditions between 2500 and 2300 years $B P$ is recorded in all three cores. The molluscan record for core $134 \mathrm{~B}$ ends at about 2300 years BP. The upper estuarine interval recorded between 2500 and 2300 years BP in cores $12 \mathrm{~B}$ and $134 \mathrm{~B}$ apparently started about 2600 years BP in core $100 \mathrm{~A}$ and lasted until possibly about 2200 years BP. From then until at least one or two hundred years ago the $100 \mathrm{~A}$ site was inhabited by transitional mollusc assemblages. Although no molluscs were present in the upper $20 \mathrm{~cm}$ of core 100A, molluscs from east of Bay du Vin Island indicate upper estuarine conditions at present in proximity to the site of this core. These observations suggest a change in Huckleberry Gully from less, to more restricted circulation - an interpretation that is supported by Reinson's (1977) contention that rapid shoaling in recent times has decreased the importance of this channel as an entrance for marine waters.

\section{DISCUSSION}

Although three cores give an inadequate coverage of the Inner Bay as a whole, they do make possible some general conclusions with regard to environmental changes that occurred near the head of the Bay during the past 4500 years. Glacier ice may have retreated from the general area more than 12000 years ago (Schafer 1977), and sea level in the Miramichi Estuary 4000 years ago was probably essentially the same as at present (Andrews and Tyler 1977, Figs. 3, 7). Bartlett and Molinsky (1972) suggest that baymouth bar systems that presently restrict circulation within most bays along the coast of northeastern New Brunswick were probably developed between 4500 and 2200 years BP. Bousfield and Thomas (1975, Fig. 7) have postulated that the waters in this region of the southern Gulf of $\mathrm{st}$. Lawrence had reached temperate-zone values (Summer surface temperatures $>18^{\circ} \mathrm{C}$ ) as early as 7000 years BP. These environmental changes are in general agreement with changes in circulation in the Inner Bay that have been inferred from the fossil assemblages.

Sediment stratigraphy based on seismic evidence suggests a somewhat similar Holocene history for the Inner Bay. Howells and McKay (1977) identified a prominent upper seismic reflector in the Bay that occurs between 2.5 and $7 \mathrm{~m}$ below the sediment-water interface. They concluded that this reflector possibly defined the erosional surface of a marine terrace that was formed about 4500 to 3000 years BP. Their conclusion was based on a comparison of its average depth with time-water depth plots given by Kranck (1972). The seismic profiles of Howells and McKay (1977) show a thick wedge of sandy sediment lying between this reflector and bedrock. This sand is probably glacio-fluvial in origin, and may have been reworked to form the initial barrier bar at the eastern end of the Bay during the eustatic sea level rise of the upper Holocene.

Textural changes recorded in several of the cores collected by Howells and McKay (1977) also support the contention of an erosional and reworking phase of early upper Holocene age associated with a transgressing sea. This event is also reflected by the onset of sediment coarsening at about the $250-\mathrm{cm}$ level in core 12B (extrapolated $\mathrm{C}^{14}$ age $=3845$ years $\mathrm{BP}$ ), and at the $315-\mathrm{cm}$ level in core 134B (extrapolated $C^{14}$ age $=3627$ years BP). The pronounced nature of these changes in the sediment texture may be indicative of both variations in the degree of development of the barrier island system through time, and (or) of previously described lithofacies shifts that have occurred in recent times (LaBerge 1977).

World-wide eustatic rise in sea level (Milliman and Emery 1968) and crustal subsidence (Grant 1970, Kranck 1972) could account for a 2- to 4-m rise in relative sea level in this area of the Gulf of St. Lawrence during the past 3500 years. This rise could have provided the requisite conditions for the formation of the barrier island system which, because of the resulting decrease in wave energy, would have accelerated the accumulation of comparatively fine sediments in the deeper offshore areas of the Inner Bay. It is possible that the present configuration of the barrier island system 


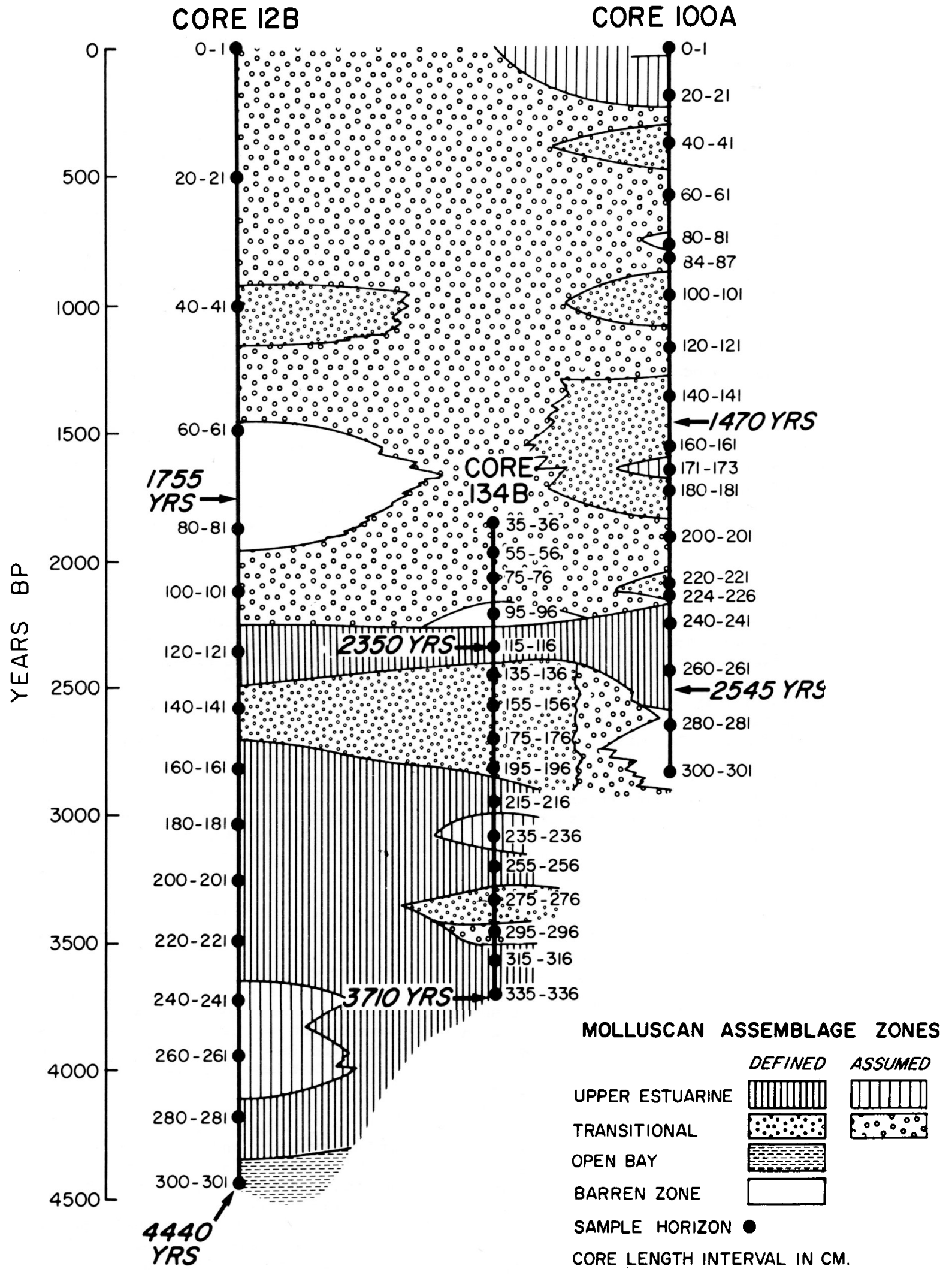

FIG. 4 Comparison of molluse assemblage zones between cores. 
is less than 3600 years old and that its formation coincides with the following: (1) the availability of sediment from both the Miramichi Esturary and adjacent areas to the northeast, and (2) the development of the present-day pattern of longshore current transport of sediment. The foraminiferal evidence indicates a profound change from an open bay towards a transitional environment in the bay at about 2500 to 2300 years BP, as indicated in cores $134 \mathrm{~B}$ and $100 \mathrm{~A}$ that hay reflect an accelerated phase of development of the barrier island system. During that time interval, the molluscs in two of the cores examined indicate a change from transitional to upper estuarine conditions. However, in core 12B, mollusc assemblage data suggest a radical and considerably earlier change from an open-bay to an upper-estuarine environment that is first evident about 4300 years BP in this part of the Bay.

Changes in the position and number of barrier island channels, and the opening and closing of channels (e.g., Huckleberry Gulley), may have also influenced, indirectly, the observed temporal variation of foraminiferal and molluscan thanatotopes interpreted in the cores. It is interesting to note that generally the molluscs and foraminifera assemblage data are one step out of phase, i.e., molluscs indicate upper estuarine conditions when foraminifera indicate transitional, and suggest transitional environments when foraminifera suggest open-bay conditions (Fig. 5). This time lag is probably related to the response of the two types of organisms to changing conditions and the time required for the various species to accomodate to the change.

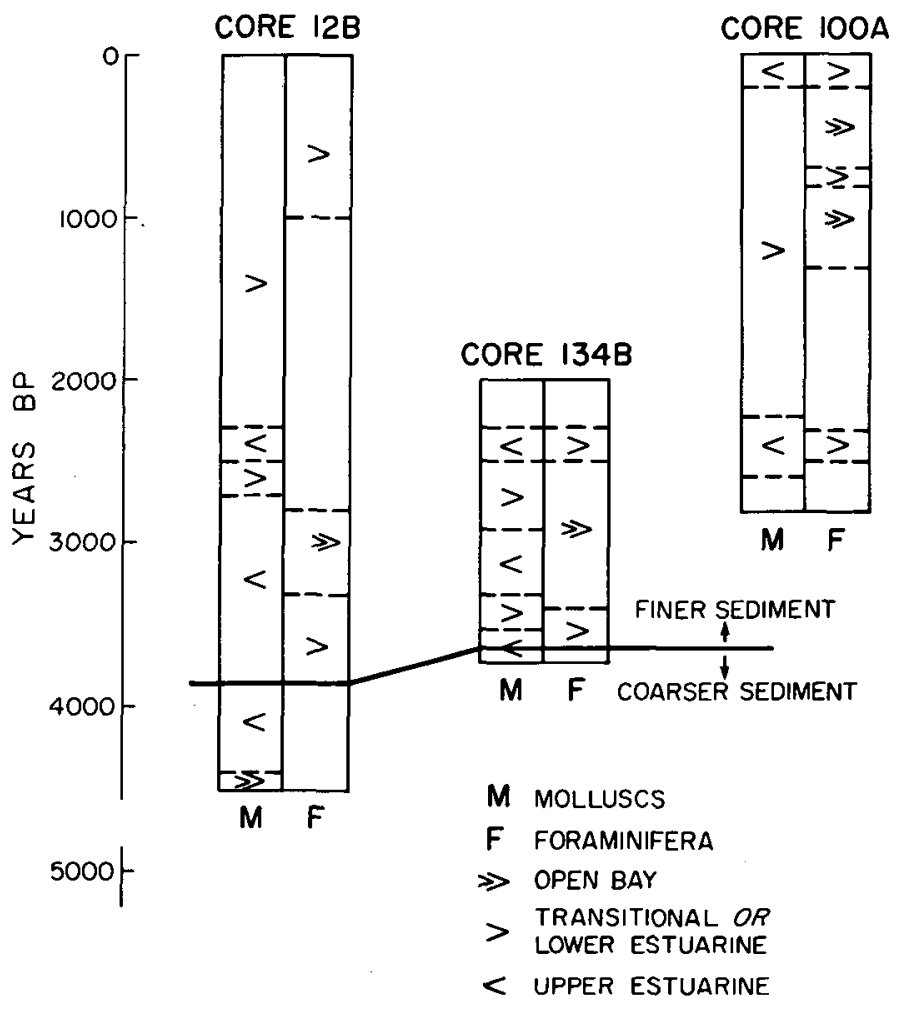

FIG. 5 Comparison between molluscan and foraminiferal data.
Variations in the tidal circulation pattern in the Inner Bay appear to have been especially pronounced near station 100A. These conditions may be related to the fact that this location lies within the axis of an older major channel and therefore could have been influenced significantly by marine water entering or leaving the Inner Bay through Hucklebery Gulley and the presently infilled Fox Channel. A counterclockwise circulation pattern of bottom water during flood tide may have existed near the western end of the Bay du Vin Island at a time when Fox Channel and Huckleberry Gulley were both open and had a larger total crosssection (i.e. 1300 to 300 years BP). Such a pattern, comprising currents that were possibly stronger than those presently operating in this area, could have produced an expansion of the open-bay thanatotope observed around the western end of the Island by Scott et al 1977, Fig. 2) show a relatively $(>10 \mathrm{~m})$ channel that extends around the western end of the island. This feature appears to be related to a similar channel that is situated on the seaward side of Huckleberry Gulley. Both channel features may be the geomorphic expression of an older and more vigorous circulation pattern. Bousfield's (1955) circulation data show a flood-tide current of surface water that flows westward at a rate of $1.3 \mathrm{~m} \mathrm{~s}^{-1}$ into the Inner Bay and then passes around the western end of Bay du Vin Island. This counterclockwise pattern could be a residual analogue of a more intense current that eroded and maintained a once-continuous $10-\mathrm{m}$ deep channel lying between the western end of Bay du Vin Island and Huckleberry Gulley.

Recent studies (MCCann et al 1977, Reinson 1977) have indicated that the southernmost inlet of the Bay (Huckleberry Gulley) has undergone rapid shoaling in recent times because of a littoral drift reversal process that is controlled by the interaction of northwesterly moving longshore currents with bedrock headlands at the southern end of the Bay. These drift processes caused the infilling of both Fox Channel and Huckleberry Gulley and apparently have contributed to the establishment of transitional conditions on the south side of Bay du Vin Island in modern times. On the basis of foraminiferal evidence from core 100A a somewhat similar, but temporary channel-infilling process may have occurred in this area about 800 to 700 years BP. This process is inferred from an increase in the number of $A$. cassis specimens, and by the occurrence of the marshrelated species, $M$. fusca in this part of the Inner Bay.

\section{CONCLUSIONS}

Assemblages of foraminifera and molluscs from cores in the western part of Inner Miramichi Bay reflect changes in environmental conditions and estuarine circulation patterns from 4500 years BP to the present. Possibly because of differences in sensitivity and rate of response to change, the molluscs and foraminifera do not always suggest the same zone (i.e., open bay, transitional, or upper estuarine) in the same place at the same time. However, they agree generally as to the direction of change (e.g., more saline to less saline, or vice versa).

Cessation of widespread open-bay conditions in the western part of the Inner Bay may be associated with the formation of the barrier island system. 
The presence of molluscs in core $12 \mathrm{~B}$ suggest that this event may date from as early as 4400 years BP. Foraminifera assemblages in core $134 \mathrm{~B}$ hint alternatively that it may not have occurred until as late as 2500 years BP. Both dates are within the time frame of 4500 to 2200 years BP that was postulated by Bartlett and Molinsky (1972) for the formation of barrier bay systems along this part of the New Brunswick coast.

The opening and closing of Huckleberry Gulley channel during the past 1300 years is suggested by changes in species proportions particularly in the foraminiferal assemblages. Occurrences of both foraminifera and mollusc species are in agreement with hypotheses on the most recent shoaling of the Gulley and the infilling of Fox Channel.

Fossil assemblage data for the past 4500 year time interval concur in general with seismic and sediment evidence in regard to the formation of the barrier island system and with responses in tidal circulation and other environmental processes that are linked to the opening, infilling and (or) relocation of inter-island channels.

\section{REFERENCES}

ANDREWS, J.T. and TYLER, K. 1977. The observed postglacial recovery of Québec and Nouveauquêbec since 12,000 B.P.; Géographie physique et Quaternaire, v. XXXI, no. 3-4, pp. 389-400.

BARTLETT, G.A. and MOLINSKY, L. 19972. Foraminifera and the Holocene history of the Gulf of St. Lawrence; Canadian Journal of Earth Sciences, v.9, pp. 1204-1215.

BOUSFIELD, E.L. 1955. Some physical aspects of the Miramichi estuary; Journal of the Fisheries Research Board of Canada, v. 12, no. 3, pp. 342-361.

BOUSFIELD, E.L. and THOMAS, M.L.H. 1975. Postglacial changes in distribution of littoral marine invertebrates in the Canadian Atlantic region; Proceedings of the Nova Scotian Institute of Science, v. 27, supplement 3, pp. $47-60$.

GRANT, D.G. 1970. Recent coastal submergence of the Maritime Provinces, Canada; Canadian Journal of Earth Sciences, v. 7, pp, 676-689.

HOWELLS, K. and MCKAY, A.G. 1977. Seismic profiling in Miramichi Bay, New Brunswick; Canadian Journal of Earth Sctences, v. 14, pp. 2909-2927.
KRANCK, K. 1972. Geomorphological development and post-Pleistocene sea-level changes, Northumberland Strait, Maritime Provinces; Canadian Journal of Earth Sciences, v. 9, pp. 835-844.

LaBERGE, M.A. 1977. The spatial and temporal distribution of foraminiferal populations within Inner Miramichi Bay, New Brunswick; B.Sc. thesis, Department of Geology, Dalhousie University, Halifax, Nova Scotia, $67 \mathrm{pp}$.

MCANDREWS, J.H. 1977. Pollen analysis of 141 sediment core samples from the Miramichi estuary, New Brunswick; Unpublished report (Contract 07SS-23420-7-M506, Dept., E., M. \& R), $6 \mathrm{pp}$.

MCCANN, S.B., REINSON, G.E. and ALMON, J.W. 1977. Tidal inlets of the southern Gulf of St. Lawrence, Canada, in Coastal Sediments 77 , Fifth symposium of the Waterway, Port, Coastal and Ocean Division of the American Society of Civil Engineering, South Carolina, pp. 504-519.

MILLIMAN, J.D. and EMERY, K.O. 1968. Sea levels during the past 35,000 years; Science, v. 162 , pp. 1121-1123.

REINSON, G.E. 1977. Tidal-current control of submarine morphology at the mouth of the Miramichi estuary, New Brunswick; Canadian Journal of Earth Sciences, v. 14, pp. 2524-2532.

SCHAFER, C.T. 1977. Distribution and depositional history of sediments in Baie de Chaleurs, Gulf of St. Lawrence; Canadian Journal of Earth Sciences, v. 14, pt. 1, pp. 593-605.

SCHAFER, C.T., SMITH, J.N. and COLE, F.E. (in preparation), Recent changes in the benthic environment of Inner Miramichi Bay.

SCOTT, D.B., MEDIOLI, F.S. and SCHAPER, C.T. 1977. Temporal changes in foraminiferal distributions in Miramichi River estuary, New Brunswick; Canadian Journal of Earth Sciences, v. 14, no. 7 , pp. 1566-1587. 